\title{
Correlation between the infestation level of Sitophilus zeamais Motschulsky, 1855 (Coleoptera, Curculionidae) and the quality factors of stored corn, Zea mays L. (Poaceae) ${ }^{1}$
}

\author{
Maria Aparecida Braga Caneppele ${ }^{2,3}$ \\ Carlos Caneppele ${ }^{2,3}$ \\ Flávio Antonio Lázzari ${ }^{4}$ \\ Sonia Maria Noemberg Lázzari ${ }^{5}$
}

\begin{abstract}
This experiment was carried out in order to evaluate the effect of Sitophilus zeamais on physical, physiological and sanitary quality of stored corn. Samples of $500 \mathrm{~g}$ of the hybrid OC-705, in three replicates, were conditioned in glasses covered with a screened lid, and kept in chamber at $25 \pm 2^{\circ} \mathrm{C}, 70 \pm 5 \% \mathrm{RH}$ and $12 \mathrm{~h}$ of photophase, for 150 days. The infestation levels were $0,5,15$ and 50 adults/replicate, for the storage periods of $30,60,90,120$ and 150 days. The moisture content, classification, weight loss, germination and internal infestation were evaluated monthly. Significant inverse correlations were verified between the number of insects and both the germination and the weight loss; also between the internal infestation and the germination and the standard type. The presence of $S$. zeamais showed a positive correlation with the weight loss, what means that the internal and external infestations contribute to the reduction of physiological and physical quality of corn seeds. The mean dry matter loss was $0,36 \% /$ day, corresponding to a consumption of $0,0001 \% /$ insect/month. As the result of those damages, the product suffered reduction of the commercial grade in 30 days, with significant loss in all quality factors.
\end{abstract}

KEYwords. Maize weevil ; quality factors; stored corn; commercial grade.

\section{INTRODUCTION}

Corn production in Brazil represents $38 \%$ of the total cereal grains and oilseeds produced in the country, with $33 \%$ growth in the last five years positioning the country on the second place in the world ranking (CONAB 2002). The increment began with the selection of better hybrid seeds, appropriate fertilization, weed control, good harvesting practices, transportation, drying and storage.

Grain quality is related to its appearance, uniformity, sanitary condition, nutritional status and industrial characteristics. Damages caused by insects, molds and mishandling result into losses of quality and quantity during storage. Such losses are frequently not precisely estimated because of the difficulties involved in such endeavor. The grading system is based on discreet measurements of quality, with little attention giving to the quantity losses (KeNKel et al. 1997).

The insect damages on stored products consist mainly on the reduction of dry matter, food contamination with live or dead insects, dejection and fragments, and depreciation of the nutritional and commercial values of the end products. The food industry adopts rigid standards concerning the presence of live insects and their fragments in all kinds of foods.

FARONI (1992) comments that one larva of the rice weevil Sitophilus oryzae Linnaeus, 1763 (Coleoptera, Curculionidae), during its growth, metabolizes about $14 \mathrm{mg}$ of a single wheat kernel into carbon dioxide, water, heat and excrements, and the insect consumes about two thirds of the endosperm.

The elevation of moisture content and temperature of the grain mass is generally a result of the metabolic activity of

1. Contribuição $\mathrm{n}^{\circ} 1359$ do Departamento de Zoologia da Universidade Federal do Paraná.

2. Doutorando em Entomologia, Ciências Biológicas, Departamento de Zoologia, UFPR. Caixa Postal 19020, 81.531-980, Curitiba-PR, Brazil.

E-mail: canepele@terra.com.br

3. Núcleo de Tecnologia em Armazenagem NTA/FAMEV/UFMT/ 78070-900, Cuiabá-MT, Brazil.

4. Fitopatologista Autônomo. E-mail: lazzari@brturbo.com

5. Departamento de Zoologia, UFPR. Caixa Postal 19020, 81531-980, Curitiba-PR, Brazil. E-mail: lazzari@ufpr.br 
insects (PuZZi 1986) and molds that are usually associated to insects and mites (LAZZARI 1997).

The management of quality should consider temperature variations, insect population fluctuation and type of damages in order to establish an appropriate control (SUBRAMANYAN \& Hagstrum 2000).

This research had the objective of measuring the impact of different infestation levels of the maize weevil, S. zeamais, on the overall quality of stored corn, considering moisture content, internal and external insect infestation, weight loss, and grain grading factors.

\section{MATERIAL AND METHODS}

Glass vials with $500 \mathrm{~g}$ of hybrid corn seeds (OC-705 intermediate hardness kernel group, with $10 \%$ moisture content), covered with a screened lid, in three replicates, were used to compose the treatments. The infestation levels were: $0,5,15$, and 50 adults of non sexed $S$. zeamais per replicate for the periods of $30,60,90,120$ and 150 days. The vials were placed randomly in an environmental chamber, at $25 \pm 2^{\circ} \mathrm{C}$ and $70 \pm 5 \%$ relative humidity $(\mathrm{RH})$ during 150 days.

The moisture content (MC\%) of seeds was determined with samples of $5 \mathrm{~g}$ in three replicates, at $105^{\circ} \mathrm{C}$ for $24 \mathrm{~h}$. For the germination tests, four replicates of 50 seeds were set on a wet paper roll and placed in a germination chamber at $25^{\circ} \mathrm{C}$, with readings at the fourth and seventh days (BRASIL 1992).

Internal infestation was evaluated based on the standard seed analysis established by BrASIL (1992), in two replicates of 100 kernels, submerged in water for $24 \mathrm{~h}$, then cut longitudinally to evaluate the presence of insect stages.

The external infestation was evaluated through sieving with $12,18,20$ and 30 mesh, counting and discarding the insects (Instituto Adolfo Lutz 1985).

For grain grading (insect damaged kernels - IDK, moldy kernels and the type ), $250 \mathrm{~g}$ seed samples of each treatment were evaluated, based on Norm 845 - 8/11/1976 (BRASIL 1976).

Weight loss was determined by three different techniques: a) PI: Method proposed by HaRRIS \& LindBLAD (1978), based on gravimetric test that counts and weighs damaged and non damaged seeds (two replicates of 100 seeds), and the values applied to the formula:

$$
\begin{aligned}
& \% \text { Weight loss }=\frac{\mathrm{Nd} \times \text { Pnd Pd } \times \text { Nnd }}{(\mathrm{Nd}+\mathrm{Nnd}) \times \mathrm{Pnd}} \\
& \mathrm{Nd}=\text { number of damaged kernels } \\
& \mathrm{Pnd}=\text { weight of non damaged kernels } \\
& \mathrm{Pd}=\text { weight of damaged kernels } \\
& \mathrm{Nnd}=\text { number of non damaged kernels }
\end{aligned}
$$$$
\text { where: }
$$

b) PII - Compton et al. (1998) method, it uses the modified gravimetric method, counting damaged grains and weighing of the final sample, using the formula:

$$
\% \text { Weight loss }=\frac{\text { Pnd }- \text { Pfa }}{\text { Pnd }} \quad \text { where: }
$$

Pnd $=$ weight of non damaged kernels

$\mathrm{Pfa}=$ final weigh of sample

c) PIII - Difference of Weight, where samples of kernels with different infestation levels are sifted to separate seeds, insects and powder. After insect counting, seeds and powder are weighed on a precision scale. Moisture content of seeds was determined as described previously to calculate the weight loss based on matter lost at each evaluation date.

The statistical design was completely randomized in a factorial outline $(4 \times 5)$ with three replicates, being four infestation levels of S. zeamais ( $0,5,15$ and 50) and five storage periods (30, 60, 90, 120 and 150 days). The data were analyzed separately by variance analysis, and comparatively by the mean analysis of Pearson's correlation. The variables MC\%, germination, molds, losses (PI, PII, PIII) and grain type were transformed to $\arcsin \sqrt{\mathrm{X} / 100}$; the internal and external insect infestation to $\log \mathrm{x}$. The means were compared by the Tukey test at $5 \%$ of probability.

\section{RESULTS AND DISCUSSION}

Considering the physical and physiological parameters, on Table I, it can be noticed that MC\% was positively correlated to the number of insects and weight loss by the three determination methods (PI, PII and PIII). According to HowE (1973) and Puzzi (1986), the increase in MC\% and in IDK may be due to the galleries that expose the endosperm allowing moisture absorption by hygroscopic carbohydrates. While weight loss may result from increasing humidity that causes fungus proliferation and dry matter loss.

On Table II, one can observe that when insect population increases, the MC\% of seeds increases, proportionally to the infestation level. After 150 days of storage, the MC\% that was initially of $10 \%$ went up to $14 \%$ ( 5 insects/vial); $20 \%$ (15 insects/ vial) and 24\% (50 insects/vial). These data demonstrate the effect of metabolic activity of insects and molds on the content of water of corn seeds, as verified by Christensen \& KaUfMan 1969; Howe 1973; Matioli et al. 1979 and LaZZARi 1997.

Germination presented high inverse correlation with the number of insects, with internal infestation and with weight loss by the three determination methods (Table I). Matioli et al. (1979) working with the rice weevil S. oryzae in corn, verified that the population size and the storage period are the factors that have the highest influence on seed germination. According to HaLl (1971), insect internal infestation affects the physiological quality of seeds because most insect species feed preferentially on the tender and high proteic embryo.

Concerning the changes on quality grading and to the economic losses, it is observed, on Table I, that the number of insects presented a positive correlation with the calculated weight loss.

Tables III and IV and Figure 3A show that by the end of 150 days of storage, for the level of 5 insects/vial, the final insect population was 629 individuals and the weight loss averaged 43,$9 ; 30,1$; and 58,4 g, respectively by PI, PII and PIII methods. 
Table I. Coefficients of simple correlation (r) among the variables analyzed to evaluate physical, physiological and sanitary quality of corn seeds (hybrid OC-705) and different infestation levels $\left(0,5,15\right.$, and 50) of Sitophilus zeamais, at $25 \pm 2^{\circ} \mathrm{C}, 70 \pm 5 \%$ RH and photophase of $12 \mathrm{~h}$.

\begin{tabular}{|c|c|c|c|c|c|c|c|c|c|c|}
\hline Variables & M & $\mathrm{MC}$ & IDK & $\mathrm{TP}$ & INS & PI & PII & PIII & INF & G \\
\hline M & 1,0000 & & & & & & & & & \\
\hline $\mathrm{MC}$ & 0,7516 & 1,0000 & & & & & & & & \\
\hline IDK & 0,6354 & 0,6119 & 1,0000 & & & & & & & \\
\hline TP & 0,5217 & 0,6160 & 0,8751 & 1,0000 & & & & & & \\
\hline INS & 0,8468 & 0,8887 & 0,7778 & 0,7663 & 1,0000 & & & & & \\
\hline PI & 0,8675 & 0,9177 & 0,7474 & 0,7234 & 0,9513 & 1,0000 & & & & \\
\hline PII & 0,8322 & 0,9291 & 0,7377 & 0,7493 & 0,9657 & 0,9508 & 1,0000 & & & \\
\hline PIII & 0,8484 & 0,9246 & 0,8721 & 0,7443 & 0,9553 & 0,9414 & 0,9813 & 1,0000 & & \\
\hline INF & 0,6700 & 0,7709 & $-0,8525$ & 0,9143 & 0,8994 & 0,8729 & 0,8713 & 0,8557 & 1,0000 & \\
\hline G & 0,7327 & $-0,8416$ & 0,5296 & $-0,8415$ & $-0,9484$ & $-0,9147$ & $-0,9164$ & $-0,8997$ & $-0,9557$ & 1,0000 \\
\hline
\end{tabular}

$\mathrm{M}=$ Molded seeds; $\mathrm{MC}=$ moisture content; IDK = Insect damaged kernels; TP = commercial type; INS = number of insects; PI = weight loss according to HarRis \& LindBlad (1971); PII = loss according to COMPTON et al. (1998); PIII = loss for weight difference; INF = internal infestation; G = germination values significant at $1 \%$ of probability.

For 15 insects, the final number was 1215 individuals and the average weight loss was 85,$1 ; 69,6$; and $93,0 \mathrm{~g}$. For 50 insects, ending with 1541 individuals, the average loss was $114 ; 90,1$; and $133,0 \mathrm{~g}$, by the three methods.

Therefore, the data show that a population of insects three or 10 folds higher does not necessarily correspond to a weight loss of the same order. From 5 to 15 insect infestation, weight loss almost doubled, but with 50 insects (10 times more) the loss was only two and a half folds and not 10 times as one can suppose. That information is of great importance for managing stored grains and to maintain product quality.

Although different values were obtained by the methods adopted to evaluate weight losses, the three of them can be regarded as reliable towards this purpose. However, the method
PII by Compton et al. (1998) was more consistent and does not superestimate losses as the others do. Thus, it should be adopted besides one of the others to determine weight losses.

Grain grading was correlated to external and internal infestations of kernels, expressing numerically that the higher the insect infestation the greater the changes in commercial standards; it means that insect infestation lowers the grain type. The number of damaged kernels showed a high negative correlation with the percentage of germination and a positive correlation with grain type. Thus, insect infestation reduces significantly the physiological quality of corn seeds and affects the commercial grain grading.

In relation to sanitary quality (Table I), a positive correlation between the presence of fungi and insects was observed,

Table II. Mean values of moisture content (MC\% - wet base), germination, internal infestation and presence of molds in samples of $500 \mathrm{~g}$ of corn seeds (hybrid OC-705) with different levels of infestation of Sitophilus zeamais, for 150 days; at $25 \pm 2^{\circ} \mathrm{C}, 70 \pm 5 \%$ RH and photophase of $12 \mathrm{~h}$.

\begin{tabular}{|c|c|c|c|c|c|c|c|c|c|c|c|c|c|c|c|c|}
\hline \multirow{2}{*}{$\begin{array}{l}\text { Period } \\
\text { (days) }\end{array}$} & \multicolumn{4}{|c|}{$\begin{array}{c}\text { Moisture content }(\mathrm{MC} \%) \\
(\%)\end{array}$} & \multicolumn{4}{|c|}{$\begin{array}{c}\text { Germination } \\
(\%)\end{array}$} & \multicolumn{4}{|c|}{$\begin{array}{l}\text { Internal infestation } \\
\qquad(\%)\end{array}$} & \multicolumn{4}{|c|}{$\begin{array}{l}\text { Molded kernels } \\
\qquad(\%)\end{array}$} \\
\hline & 0 & 5 & 15 & 50 & 0 & 5 & 15 & 50 & 0 & 5 & 15 & 50 & 0 & 5 & 15 & 50 \\
\hline 0 & $10 \mathrm{Aa}$ & $10 \mathrm{Aa}$ & $10 \mathrm{Aa}$ & $10 \mathrm{Aa}$ & $96 \mathrm{Aa}$ & $98 \mathrm{Aa}$ & $97 \mathrm{Aa}$ & $98 \mathrm{Aa}$ & $0,0 \mathrm{Aa}$ & $0,0 \mathrm{Aa}$ & $0,0 \mathrm{Aa}$ & $0,0 \mathrm{Aa}$ & $2,56 \mathrm{Aa}$ & $3,73 \mathrm{Aa}$ & $2,72 \mathrm{Aa}$ & $3,05 \mathrm{Aa}$ \\
\hline 30 & $11 \mathrm{Aa}$ & $11 \mathrm{Aa}$ & $11 \mathrm{Aa}$ & $11 \mathrm{Aab}$ & $95 \mathrm{Aa}$ & $91 \mathrm{Aa}$ & $94 \mathrm{Aa}$ & $94 \mathrm{Aa}$ & $0,0 \mathrm{Aa}$ & $5,8 \mathrm{Aa}$ & 7,3 Aa & $10,5 \mathrm{Aab}$ & $3,66 \mathrm{Aa}$ & $4,03 \mathrm{Aa}$ & $4,80 \mathrm{Aa}$ & $3,57 \mathrm{Aa}$ \\
\hline 60 & $11 \mathrm{Aa}$ & $11 \mathrm{Aa}$ & $11 \mathrm{Aa}$ & $11 \mathrm{Aab}$ & $95 \mathrm{Aa}$ & $94 \mathrm{Aa}$ & $89 \mathrm{Aab}$ & $78 \mathrm{Aa}$ & $0,0 \mathrm{Aa}$ & $8,0 \mathrm{ABa}$ & $12,8 \mathrm{ABa}$ & $28,2 \mathrm{Bb}$ & $2,46 \mathrm{Aa}$ & $3,38 \mathrm{Aa}$ & $2,35 \mathrm{Aa}$ & $2,36 \mathrm{Aa}$ \\
\hline 90 & $11 \mathrm{Aa}$ & $11 \mathrm{Aa}$ & $12 \mathrm{Aab}$ & $13 \mathrm{Aab}$ & $94 \mathrm{Aa}$ & $81 \mathrm{Aba}$ & $66 \mathrm{BCb}$ & $47 \mathrm{Cb}$ & $0,0 \mathrm{Aa}$ & $41,0 \mathrm{Bb}$ & $51,0 \mathrm{BCb}$ & $72,0 \mathrm{Ccd}$ & $3,89 \mathrm{Aa}$ & $2,82 \mathrm{Aa}$ & $2,44 \mathrm{Aa}$ & $2,40 \mathrm{Aa}$ \\
\hline 120 & $11 \mathrm{Aa}$ & $12 \mathrm{Aa}$ & $14 \mathrm{Ab}$ & $15 \mathrm{Ab}$ & $96 \mathrm{Aa}$ & $56 \mathrm{Bb}$ & $34 \mathrm{Bc}$ & $41 \mathrm{Bb}$ & $0,0 \mathrm{Aa}$ & $49,0 \mathrm{Bb}$ & $78,0 \mathrm{BCc}$ & $71,0 \mathrm{Cc}$ & 2,71Aa & $1,94 \mathrm{Aa}$ & $15,49 \mathrm{Bc}$ & $38,67 \mathrm{Cb}$ \\
\hline 150 & $10 \mathrm{Aa}$ & $14 \mathrm{Aa}$ & $20 \mathrm{Bc}$ & $24 \mathrm{Bc}$ & $95 \mathrm{Aa}$ & $51 \mathrm{Bb}$ & $14 \mathrm{Cc}$ & $08 \mathrm{Cc}$ & $0,0 \mathrm{Aa}$ & $61,0 \mathrm{Bc}$ & $90,0 \mathrm{Cc}$ & $97,0 \mathrm{Cd}$ & $3,36 \mathrm{Aa}$ & $4,23 \mathrm{Aa}$ & $27,46 \mathrm{Bd}$ & $37,40 \mathrm{Cb}$ \\
\hline SMD & \multicolumn{4}{|c|}{7,1} & \multicolumn{4}{|c|}{24,2} & \multicolumn{4}{|c|}{0,4} & \multicolumn{4}{|c|}{7,7} \\
\hline $\begin{array}{l}\mathrm{CV} \\
(\%)\end{array}$ & \multicolumn{4}{|c|}{$6,75^{(1)}$} & \multicolumn{4}{|c|}{$10,67^{(1)}$} & \multicolumn{4}{|c|}{$16,20^{(2)}$} & \multicolumn{4}{|c|}{$15,50^{(2)}$} \\
\hline
\end{tabular}

Means followed by the same letter - capitals in the lines between the parameter, and lower cases in the columns among the time periods, do not differ from each other by the Tukey test, at $5 \%$ of probability.

SMD - Significant Minimum Difference for the mean comparisons.

CV - Coefficient of Variation

(1) data transformed to $\arcsin \sqrt{ } \mathrm{X} / 100$

(2) data transformed to $\log \mathrm{X}$ 
Table III. Mean values of the number of insects, standard type, and insect damaged kernels in samples of $500 \mathrm{~g}$ of corn seeds (hybrid OC-705), with different infestation levels of Sitophilus zeamais, for 150 days; at $25 \pm 2^{\circ} \mathrm{C}, 70 \pm 5 \% \mathrm{RH}$ and photophase of $12 \mathrm{~h}$

\begin{tabular}{|c|c|c|c|c|c|c|c|c|c|c|c|c|}
\hline \multirow[t]{2}{*}{$\begin{array}{l}\text { Period } \\
\text { (days) }\end{array}$} & \multicolumn{4}{|c|}{$\begin{array}{l}\text { External Infestation } \\
\qquad\left(\mathrm{n}^{\mathrm{o}} \text { insects }\right)\end{array}$} & \multicolumn{4}{|c|}{$\begin{array}{l}\text { Standard } \\
\text { type }\end{array}$} & \multicolumn{4}{|c|}{$\begin{array}{l}\text { Insect damaged kernels } \\
(\%)\end{array}$} \\
\hline & 0 & 5 & 15 & 50 & 0 & 5 & 15 & 50 & 0 & 5 & 15 & 50 \\
\hline 0 & $0 \mathrm{Aa}$ & $5 \mathrm{Aa}$ & $15 \mathrm{Aa}$ & $50 \mathrm{Aa}$ & $1 \mathrm{Aa}$ & $1 \mathrm{Aa}$ & $1 \mathrm{Aa}$ & $1 \mathrm{Aa}$ & $0,0 \mathrm{Aa}$ & $0,0 \mathrm{Aa}$ & $0,0 \mathrm{Aa}$ & $0,0 \mathrm{Aa}$ \\
\hline 30 & $0 \mathrm{Aa}$ & $5 \mathrm{Aa}$ & $15 \mathrm{Aa}$ & $50 \mathrm{Aa}$ & $1 \mathrm{Aa}$ & $1 \mathrm{Aa}$ & $2 \mathrm{Bb}$ & $2 \mathrm{Bb}$ & $0,0 \mathrm{Aa}$ & $2,45 \mathrm{Aa}$ & $4,52 \mathrm{Aa}$ & $8,18 \mathrm{Aab}$ \\
\hline 60 & $0 \mathrm{Aa}$ & $27 \mathrm{Aa}$ & $71 \mathrm{Aa}$ & $151 \mathrm{Aa}$ & $1 \mathrm{Aa}$ & $1 \mathrm{Aa}$ & $2 \mathrm{Bb}$ & $3 \mathrm{Cc}$ & $0,0 \mathrm{Aa}$ & $3,06 \mathrm{Aa}$ & $12,84 \mathrm{ABa}$ & $19,61 \mathrm{Bb}$ \\
\hline 90 & $0 \mathrm{Aa}$ & $153 \mathrm{Ba}$ & $212 \mathrm{BCa}$ & $467 \mathrm{Cb}$ & $1 \mathrm{Aa}$ & $4 \mathrm{Bb}$ & $4 \mathrm{Bc}$ & $4 \mathrm{Bd}$ & $0,0 \mathrm{Aa}$ & 5,39 Aa & $34,17 \mathrm{Bb}$ & $49,49 \mathrm{Cc}$ \\
\hline 120 & $0 \mathrm{Aa}$ & $429 \mathrm{Bb}$ & $633 \mathrm{Bb}$ & $899 \mathrm{Cc}$ & $1 \mathrm{Aa}$ & $4 \mathrm{Bb}$ & $4 \mathrm{Bc}$ & $4 \mathrm{Bd}$ & $0,0 \mathrm{Aa}$ & $59,05 \mathrm{Bb}$ & $80,36 \mathrm{Cc}$ & $78,29 \mathrm{Cd}$ \\
\hline 150 & $0 \mathrm{Aa}$ & $629 \mathrm{Bb}$ & $1215 \mathrm{Cc}$ & $1541 \mathrm{Dd}$ & $1 \mathrm{Aa}$ & $4 \mathrm{Bb}$ & $4 \mathrm{Bc}$ & $4 \mathrm{Bd}$ & $0,0 \mathrm{Aa}$ & $45,66 \mathrm{Bb}$ & $56,35 \mathrm{Bd}$ & $51,18 \mathrm{Bc}$ \\
\hline SMD & \multicolumn{4}{|c|}{0,39} & \multicolumn{4}{|c|}{0,35} & \multicolumn{4}{|c|}{16,0} \\
\hline $\begin{array}{l}\mathrm{CV} \\
(\%)\end{array}$ & \multicolumn{4}{|c|}{$7,39^{(1)}$} & \multicolumn{4}{|c|}{$6,2^{(2)}$} & \multicolumn{4}{|c|}{$20,1^{(2)}$} \\
\hline
\end{tabular}

Means followed by the same letter - capitals in the lines between the parameter, and lower cases in the columns among the time periods, do not differ from each other by the Tukey test, at $5 \%$ of probability.

SMD - Significant Minimum Difference for the mean comparisons.

CV - Coefficient of Variation

(1) data transformed to $\log X$

(2) data transformed to $\arcsin \sqrt{ } \mathrm{X} / 100$

corroborating with DuNKEL (1988), who confirms this fact, mentioning that such association improve the conditions for development of these organisms. On Table II, it can be observed that mold damage increased with insect infestation, agreeing with LAZZARI (1997) and BETI et al. (1995), who mentioned that insects can disseminate mold spores on grain mass causing weight loss. Christensen \& Meronuck (1989) also affirm that the weight loss in corn can be due to the invasion of molds, being accentuated with the increase of humidity and the storage period.

Insect damaged kernels and mold damaged kernels changed corn commercial grade (type) in 30 days of storage when infested with 15 and 50 insects $/ 450 \mathrm{~g}$ of corn. By the $90^{\text {th }}$ day, the product was classified as down graded, and the sample should be rejected according to the Brazilian standards (BRAZIL 1976). Consequently, physical losses can result in a substantial economic loss with the rejection of the product (JORDÃo 1974; BoXall 1986; АвimilHo 2002).

Physical, physiological and sanitary quality losses caused by 15 and 50 insects become significantly accentuated after the $90^{\text {th }}$ day. Internal infestation with 5, 15 and 50 insects in each treatment was significantly different by the $60^{\text {th }}$ day, while the grain type was already downgraded by the $30^{\text {th }}$ day with 15 and 50 insects (Tables II, III, IV). After 120 days from treatment there was no significant difference between the infestation levels with 15 and 50 insects for most parameters (Tables II, III and IV). It can be observed that infestation by S. zeamais has a noticeable impact on every grading factor and affects overall

Table IV. Mean values of weight loss (PI, PII, PIII) in samples of $500 \mathrm{~g}$ of corn seeds (hybrid OC-705) with different infestation levels of Sitophilus zeamais, for 150 days; at $25 \pm 2^{\circ} \mathrm{C}, 70 \pm 5 \% \mathrm{RH}$ and photophase of $12 \mathrm{~h}$.

\begin{tabular}{|c|c|c|c|c|c|c|c|c|c|c|c|c|}
\hline \multirow[t]{2}{*}{$\begin{array}{c}\text { Period } \\
\text { (days) }\end{array}$} & \multicolumn{4}{|c|}{$\begin{array}{c}\text { Weight Loss I } \\
\text { (HARRIS \& LindBLAD 1978) } \\
(\mathrm{g})\end{array}$} & \multicolumn{4}{|c|}{$\begin{array}{c}\text { Weight Loss II } \\
\text { (COMPTON et al. 1998) } \\
(\%)\end{array}$} & \multicolumn{4}{|c|}{$\begin{array}{c}\text { Weight Loss III } \\
\text { (Weight difference) } \\
(\%)\end{array}$} \\
\hline & 0 & 5 & 15 & 50 & 0 & 5 & 15 & 50 & 0 & 5 & 15 & 50 \\
\hline 0 & $0,0 \mathrm{Aa}$ & $0,0 \mathrm{Aa}$ & $0,0 \mathrm{Aa}$ & $0,0 \mathrm{Aa}$ & $0,0 \mathrm{Aa}$ & $0,0 \mathrm{Aa}$ & $0,0 \mathrm{Aa}$ & $0,0 \mathrm{Aa}$ & $0,0 \mathrm{Aa}$ & $0,0 \mathrm{Aa}$ & $0,0 \mathrm{Aa}$ & $0,0 \mathrm{Aa}$ \\
\hline 30 & $0,0 \mathrm{Aa}$ & $0,35 \mathrm{Aa}$ & $0,34 \mathrm{Aa}$ & $0,80 \mathrm{Aa}$ & $0,0 \mathrm{Aa}$ & $0,41 \mathrm{Aa}$ & $0,68 \mathrm{Aa}$ & $0,75 \mathrm{Aa}$ & $0,0 \mathrm{Aa}$ & $1,8 \mathrm{Aa}$ & $3,1 \mathrm{Aa}$ & 3,4 Aa \\
\hline 60 & $0,0 \mathrm{Aa}$ & $0,76 \mathrm{Aa}$ & $1,16 \mathrm{Aa}$ & $2,32 \mathrm{Aa}$ & $0,0 \mathrm{Aa}$ & $0,74 \mathrm{Aa}$ & 1,33 Aab & 1,99 Aab & $0,0 \mathrm{Aa}$ & 3,3 Aa & $6,0 \mathrm{Aa}$ & 8,9 Aab \\
\hline 90 & $0,0 \mathrm{Aa}$ & $2,34 \mathrm{Abab}$ & 25,2 Aba & $5,36 \mathrm{Ba}$ & $0,0 \mathrm{Aa}$ & $4,71 \mathrm{Bb}$ & $5,91 \mathrm{Bb}$ & $5,74 \mathrm{Bb}$ & $0,0 \mathrm{Aa}$ & $21,2 \mathrm{Bb}$ & $25,9 \mathrm{Bb}$ & $29,5 \mathrm{Bc}$ \\
\hline 120 & $0,0 \mathrm{Aa}$ & $6,29 \mathrm{Bb}$ & $10,04 \mathrm{Bb}$ & $15,18 \mathrm{Ca}$ & $0,0 \mathrm{Aa}$ & $5,37 \mathrm{Bb}$ & $11,94 \mathrm{Cc}$ & $14,42 \mathrm{Cc}$ & $0,0 \mathrm{Aa}$ & $24,2 \mathrm{Bb}$ & $49,6 \mathrm{Cc}$ & $64,9 \mathrm{Dd}$ \\
\hline 150 & $0,0 \mathrm{Aa}$ & $6,83 \mathrm{Bb}$ & $15,46 \mathrm{Cc}$ & $20,19 \mathrm{Cb}$ & $0,0 \mathrm{Aa}$ & $12,98 \mathrm{Bc}$ & $20,65 \mathrm{Cd}$ & $29,49 \mathrm{Dd}$ & $0,0 \mathrm{Aa}$ & $43,4 \mathrm{Bc}$ & $93,0 \mathrm{Cd}$ & $133,0 \mathrm{De}$ \\
\hline SMD & \multicolumn{4}{|c|}{1,22} & \multicolumn{4}{|c|}{0,83} & \multicolumn{4}{|c|}{1,29} \\
\hline $\begin{array}{l}\mathrm{CV} \\
(\%)\end{array}$ & \multicolumn{4}{|c|}{$20,17^{(1)}$} & \multicolumn{4}{|c|}{$12,41^{(1)}$} & \multicolumn{4}{|c|}{$10,40^{(1)}$} \\
\hline
\end{tabular}

Means followed by the same letter - capitals in the lines between the parameter, and lower cases in the columns among the time periods, do not differ from each other by the Tukey test, at $5 \%$ of probability.

SMD - Significant Minimum Difference for the mean comparisons.

CV - Coefficient of Variation

(1) data transformed to arcsin $\sqrt{ } \mathrm{X} / 100$ 

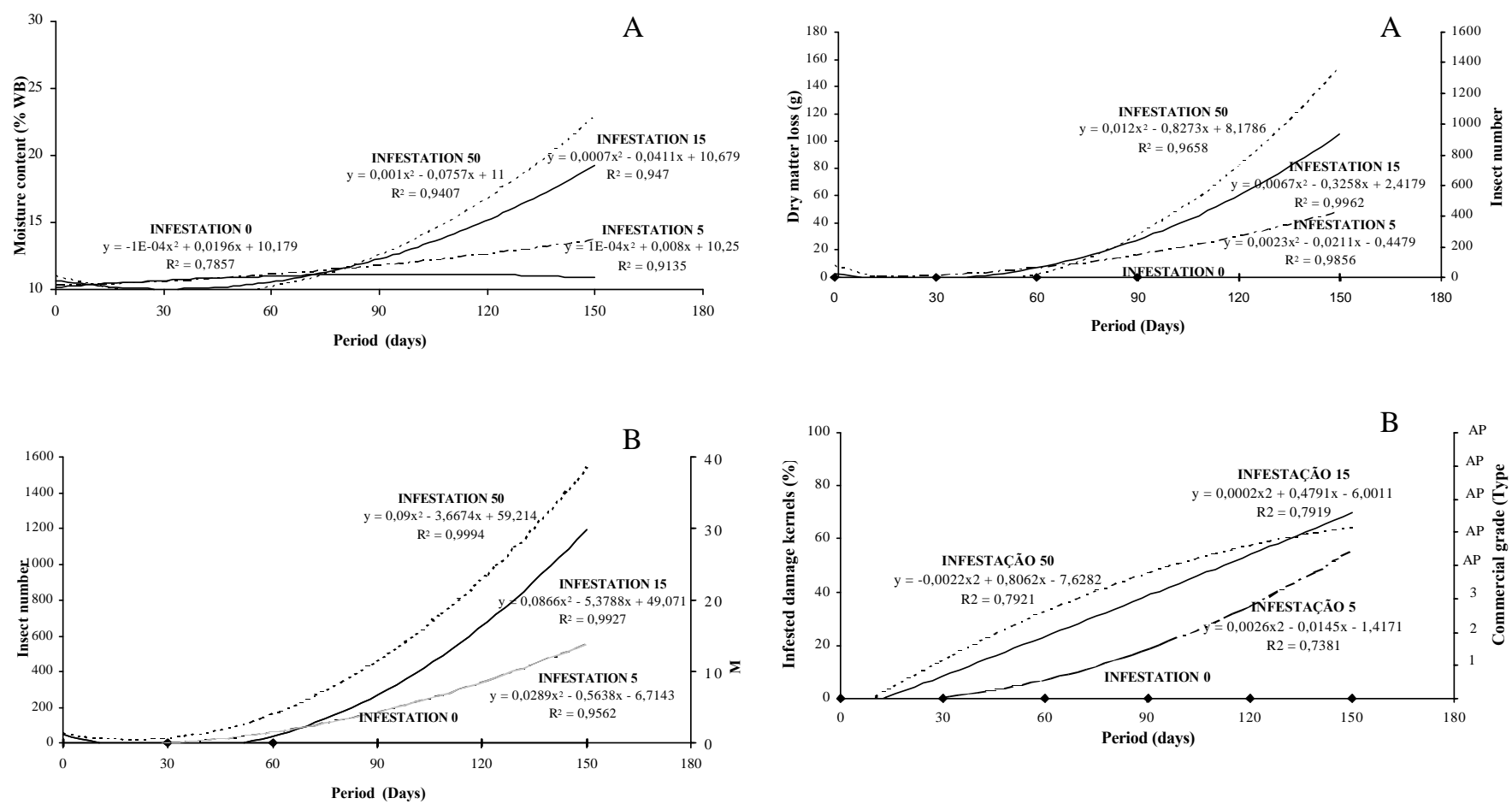

Fig. 1. Effects of the storage period and infestation level of Sitophilus zeamais (axis $\mathrm{x})$ on (axis $\mathrm{y})$ : A) moisture content (MC\%) and $\mathbf{B})$ number of adults related with molded seeds, of corn seeds (hybrid OC-705); for 150 days; at $25 \pm 2^{\circ} \mathrm{C}, 70 \pm 5 \% \mathrm{RH}$ and photophase of $12 \mathrm{~h}$.

A

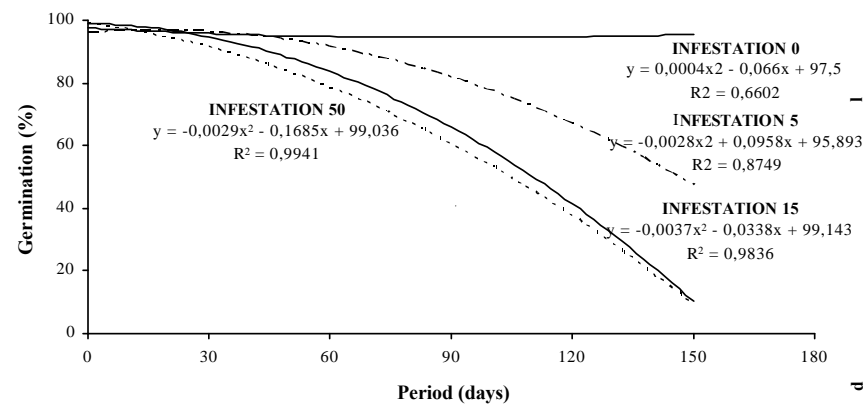

B

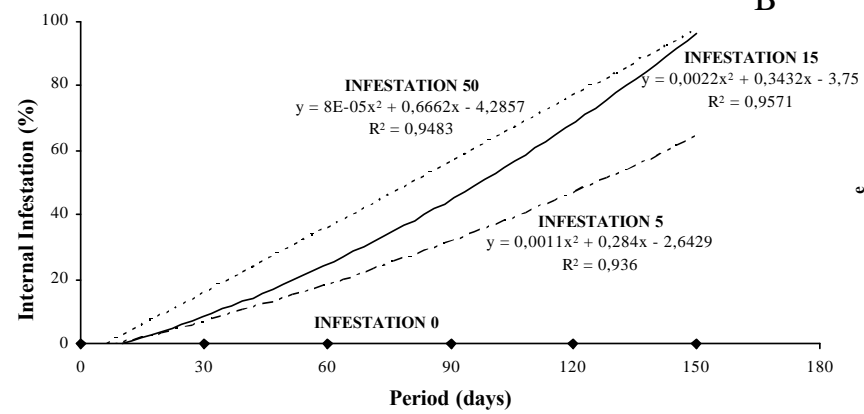

Fig. 2. Effects of the storage period and infestation level of Sitophilus zeamais (axis $\mathrm{x}$ ) on (axis $\mathrm{y})$ : A) germination and $\mathbf{B}$ ) internal infestation of corn seeds (hybrid OC-705); for 150 days; at $25 \pm 2^{\circ} \mathrm{C}, 70 \pm 5 \% \mathrm{RH}$ and photophase of $12 \mathrm{~h}$. quality.

The regression analysis indicated elevation of the humidity under the infestation levels 15 and 50, starting from the $90^{\text {th }}$ day of storage, with increasing insect number and high incidence of molds (Figure 1A and 1B). These results agree with HowE (1973), who observed a higher MC\% in grains infested by insects, and with MATIOLI et al. (1979) who attributes this fact to the extensive exposition of the endosperm to insect attack and favors the development of microorganisms on the kernels.

Internal infestation resulted in a progressive reduction of germination directly proportional to the infestation level and to the storage period (Figures 2A and 2B). According to HALL (1971), the tender germ is more susceptible to insect attack. The dry matter loss was directly proportional to the number of insects inside the kernel, what downgraded the samples (Figures 3A and 3B). The internal damages affect the physiological quality and, when they become apparent under the form of galleries and holes, they result in the IDK damage that indicates the loss of physical quality. DUРснак (1997) and Aтиі (1998) observed that the larger the grain infestation the higher was the number of fragments in the final product, and the lower the quality.

\section{CONCLUSIONS}

1. The quality factors of stored corn are significantly reduced with the increase of $S$. zeamais infestation. 
2. The increasing percentage of insect damaged kernels caused by 15 and 50 insects brings down the commercial quality or sample grade of corn in 30 days and the samples are down graded in 90 days.

3 . The average dry matter loss of $0,36 \% /$ day corresponds to a consumption of $0,0001 \% /$ insect/month, after 150 days.

4. The internal insect infestation affects the seed physiological quality reducing germination.

5. The infestation with 15 or more adults of $S$. zeamais elevates the seed moisture content that favors the proliferation of molds by the $90^{\text {th }}$ day.

6. The infestation of stored corn by S. zeamais, even in small population, affects every grading factor, and consequently the overall quality of the grain along to the storage period.

Acknowledgements. This research was partially supported by a scholarship from CAPES/PICDT-Brazil. We are thankful to Cooperativa Central Agropecuária de Desenvolvimento Tecnológico Econômico Ltda. (COODETEC) for supplying the corn seeds; to the Departamentos de Zoologia and Agronomia of the UFPR and to the Empresa Paranaense de Classificação de Produtos (CLASPAR) for the facilities and equipments to accomplish the analyses, as well as for their helpful personnel.

\section{REFERENCES}

AвıмILнo -Associação Brasileira das Indústrias Moageiras de Milho.2002. Colheita, Recebimento, Limpeza, Secagem e Armazenamento de milho. Boletim Técnico. Apucarana, ABIMILHO, $22 \mathrm{p}$.

Ати, M. В. 1998. Efeito do processamento do milho em grãos no nível de matérias estranhas encontradas no gritz e fubá. Revista do Instituto Adolfo Lutz 57(1): 57-63.

Beti, J. A.; T. W. Phillips \& E. B. Smalley. 1995. Effects of maize Weevils (Coleoptera: Curculionidae) on Production of Aflatoxin B by Aspergillus flavus in Stored Corn. Journal of Economic Entomology 88(6): 1517-1838.

Boxall, R. A. 1986. A critical review of the methodology for assessing farm-level grain losses after harvest. London, TDRI, $139 \mathrm{p}$.

Brasil. 1976. Ministério da Agricultura. Secretaria Nacional de Abastecimento e da Reforma Agrária. Secretaria de Desenvolvimento Rural. Portaria $\mathrm{n}^{0} \mathrm{845}$, de 8 de novembro de 1976. Brasília, MA-SNARA, vi+12 p.

Brasil. 1992. Ministério da Agricultura e Reforma Agrária. Secretaria Nacional de Defesa Agropecuária. Departamento Nacional de Defesa Vegetal. Coordenação de Laboratório Vegetal. Regras para Análise de Sementes. Brasília, MARA - SNDA/DNDV, 365 p.
Christensen, C. M. \& H. H. Kaufman. 1969. Grain Storage - The role of Fungi Quality Loss. Minneapolis, University of Minnesota Press., 138 p.

Christensen, C. M. \& R. A. Meronuck. 1989. Dry matter loss in yellow dent corn resulting from invasion by storage fungi. Plant Diseases 73(6): 501-503.

Compton, J. A. F; S. Floyd; A. Ofosu \& B. Agbo. 1998. The modified count and weight method: and improved procedure for assessing weight loss in stored maize cobs. Journal of Stored Product Research 34(4): 277-285.

ConAB - Companhia Nacional de Abastecimento - Disponível em: http:/ /www.conab.com.gov.br. Acesso em: Maio 2002.

DunKEL, F. V. 1988. The relationship of insects to the deterioration of stored grain by fungi. International Journal of Food Microbiology 7: 227-244.

Duрснак, L. M. 1997. Detecção de sujidades e avaliação de uma formulação de pós inertes para o controle de insetos em grãos e farinhas de trigo. Dissertação de Mestrado. Curitiba, UFPR, $77 \mathrm{p}$.

FARONI, L. R. D'A. 1992. Manejo das pragas dos grãos armazenados e sua influência na qualidade do produto final. Revista Brasileira de Armazenamento 17(1/2): 36-43.

Hall, D. W. 1971. Manipulación y almacenamiento de granos alimenticios en las zonas tropicales y subtropicales. Roma, FAO, $400 \mathrm{p}$.

Harris, K. L. \& C. J. Lindblad. 1978. Postharvest Grain Loss Assessment Methods. Minnesota, America Association of Cereal Chemist, 193 p.

Howe, R. W. 1973. Loss of viability of seed in storage attributable to infestations of insects and mites. Seed Science Technology 1: 562-586.

Instituto Adolfo Lutz. 1985. Normas Analíticas do Instituto Adolfo Lutz. São Paulo, O Instituto, 1: 533 p.

Jordão , B. A. 1974. Conseqüências dos fatores de deterioração nas características qualitativas dos grãos armazenados. Boletim do Instituto de Tecnologia de Alimentos 1-11. 1974.

Kenkel, P. ; G. Cuperus; T. Philips; R. Noyes; J. T. Criswell \& J. L. Steele. 1997. Biological preservation of grain quality; losses in storage and handling, p. 385 - 390. In: J. L. Steele \& O. K. Chung (ed.) Proceedings of the International Wheat Quality Conference, Manhattan, Kansas, USA, 18-22 May. Manhattan, Grain Industry Alliance, vi+543 p.

LAZZARI, F. A. 1997. Umidade, fungos e micotoxinas na qualidade de sementes, grãos e rações. Curitiba, Ed. Autor, $134 \mathrm{p}$.

Matioli, J. C.; A. A. Almeida. \& C. H. Matioli. 1979. Efeitos da infestação de Sitophilus oryzae sobre a germinação de sementes de milho armazenado. Revista Brasileira de Armazenamento 4(1): 15 28 .

PuZZI, D. 1986. Abastecimento e Armazenamento de grãos. Campinas, Instituto Campineiro de Ensino Agrícola, 613 p.

Subramanyan, B. \& Hagstrum, D. W. 2000. Monitoring and decision tools, p. 1-28. In: B. Subramanyan \& D. W. Hagstrum (eds.). Alternatives to pesticides in stored-product IPM. 1 ed. Massachusetts, Klumer Academic Publishers Norwell. 